\title{
Can groundwater be successfully implemented as a bulk water resource within rural Limpopo Province? Analysis based on GRIP datasets
}

\author{
Willem du Toit ${ }^{1 *}$, Martin Holland ${ }^{2}$, Reinhardt Weidemann ${ }^{3}$ and Fanie Botha ${ }^{4}$ \\ ${ }^{1}$ Department of Water Affairs, PO Box 118, Polokwane, 0700, South Africa \\ ${ }^{2}$ Deltah, PO Box 6662, Woodhill, 0076, South Africa \\ ${ }^{3}$ VSA Leboa Consulting (Pty) Ltd, PO Box 222, Polokwane, 0700, South Africa \\ ${ }^{4}$ Private Consultant, PO Box 11640, Hatfield, 0028, South Africa
}

\begin{abstract}
Groundwater is a strategic water resource in rural Limpopo Province and it accounts for almost $70 \%$ of rural domestic water supply. The resource is available throughout the Province in varying quantities and qualities depending on the hydrogeological properties of the underlying aquifer. These properties are mostly secondary in nature and are constrained by the processes of weathering, faulting, fracturing and the influence of intrusive rocks. These properties define typical fractured aquifers in which the selection of drilling sites requires a thorough scientific approach to locate a successful productive borehole. While most water service authorities in the Province have been randomly developing new boreholes with limited success rates, the analysis of datasets in the newly established groundwater data repository, the Limpopo Groundwater Resource Information Project (GRIP) demonstrates that large quantities of groundwater can be obtained and used for bulk supply if the drilling sites are scientifically selected. The GRIP dataset contains 24922 entries of which 4000 were tested. The pumping test results indicate that an estimated $576000 \mathrm{~m}^{3} / \mathrm{d}\left(210 \mathrm{Mm}^{3} / \mathrm{a}\right)$ can be sustainably abstracted from boreholes in approximately 2500 villages that are dispersed throughout the Province. However, more than $50 \%$ of these boreholes are unequipped of which 3000 can provide a combined yield of $109 \mathrm{Mm}^{3} / \mathrm{a}$ based on a $24 \mathrm{~h}$ abstraction rate. These results show that groundwater can be developed as a potential viable bulk-water supply source. This paper attempts to demonstrate, using the existing GRIP dataset, that groundwater is an underutilised resource that can be viably and cost-effectively developed as an alternative bulk water source or conjunctively with surface water.
\end{abstract}

Keywords: groundwater, GRIP, bulk water supply, information variability, borehole productivity, conjunctive use, well-field development cost, well-field yield

\section{Introduction}

Historically, groundwater has always been seen as a standalone or site-specific resource and never as regional bulk-water supply. Only as recently as 1998, with the promulgation of the National Water Act (Act No. 36 of 1998; RSA, 1998), groundwater became part of an integrated water resource; before that boreholes were mostly owned and managed by landowners. This article aims to indicate how groundwater can be rapidly and cost-effectively developed as a bulk-water resource, meeting short- to medium-term water requirements, becoming part of a truly integrated water resource. In the National Water Resource Strategy (NWRS), groundwater was not introduced as an exciting nor strategic resource, but rather pushed as a suitable resource for hand-pump installations, emergency water supply or rural use in small communities (DWAF, 2004). However, in the publication 'Strategic Planning for Water Resources in South Africa Situation Analysis' (DWA, 2009) the Department of Water Affairs (DWA) concurred that groundwater can play a significant role in larger cities/towns, for example Cape Town. Therefore, at a policy level, groundwater has come a long way and it seems that South Africa's groundwater has a bright future.

This paper was originally presented at the International Conference on Groundwater: Our Source of Security in an Uncertain Future, Pretoria, 19-21 September 2011.

* To whom all correspondence should be addressed.

Im +27 82 808-6386; e-mail: dutoitw2@dwa.gov.za
Groundwater as a water resource has a competitive advantage, especially within the short- to medium-term solution sphere; this so-called advantage can broadly be divided into 3 major aspects:

- Conjunctive resource: It can be used as an additional water resource together with surface water to meet water demands.

- Rapid development: High-yielding aquifers are quite common in South Africa and as a result they can be developed at or close to the user within a short space of time.

- Phased development: When developing a surface water resource, future demands need to be considered; as a result massive capital expenditure is required, for infrastructure which will only be used within the next 20 years to 30 years, whereas groundwater resources can be developed as the need arises.

Nevertheless, groundwater still struggles to find a path from being a scientific entity to becoming a useable water resource. As a result, the endeavour to have groundwater take its rightful place as a conjunctive water resource continues to fail. This disbelief and lack of confidence in the resource, despite the scientific evidence available within South Africa, has been created as a result of 3 specific reasons, as discussed below.

The most common question is, why not jump in and start to develop groundwater resources? If a village experiences a water shortage, boreholes are drilled, tested and equipped. This practice results in scattered, single-source, poorly-maintained water resources. This is clearly illustrated when boreholes are selected for pump testing using exactly the same approach, regardless of context, e.g. in the GRIP study areas there are 
hardly places where a non-tested borehole cannot be found within a kilometre. However, GRIP results (GRIP Limpopo Online) suggest that as much as $75 \%$ of rural Limpopo can be supplied with potable water during a drought period by simply repairing vandalised or dysfunctional boreholes (Botha, 2005).

Why the lack of confidence in the available groundwater figures? Certainly, one answer is that groundwater was the 'new kid on the block' and in the beginning there was large variability in different groundwater figures and that created discomfort in groundwater development. According to the NWRS (DWAF, 2004), the total available yield from groundwater resources in South Africa is estimated at about a 1000 $\mathrm{Mm}^{3} / \mathrm{a}$. Based on Vegter's (2001) estimation of current use of groundwater due to the development of the modern drilling rig, the use should be around $3600 \mathrm{Mm}^{3} / \mathrm{a}$, corresponding well with the figure determined by Baron et al. (1996). If Baron et al. and Vegter are correct in their assumptions, then use exceeds the NWRS figure threefold. The different figures between use and yield create uncertainty. Confusing the issue further was a groundwater exploitation potential assessment study done by Haupt (2001) for the DWAF Directorate of Water Resource Planning, in which it was concluded that the exploitable groundwater available in South Africa could be as high as $19000 \mathrm{Mm}^{3} / \mathrm{a}$.

The Waterberg Aquifer at Lephalale is an excellent example. If $S$ (storativity) is estimated at 0.00022 , then $0.7 \mathrm{Mm}^{3}$ is considered the minimum accessible volume of water if storage is utilised. However, if $S$ is 0.005 then there is $400 \mathrm{Mm}^{3}$ in storage and $1.6 \mathrm{Mm}^{3}$ per metre drawdown. This calculation changes results completely and creates uncertainty within the planning community (Botha et al., 2009).

\section{Method and analysis}

The Groundwater Resource Information Project (GRIP) was developed with the aim of assisting in the gathering of groundwater data and to use it to improve assessment and management of groundwater resources within rural South Africa (Botha et al., 2009). The project was initiated in Limpopo Province in 2002/2003 and is a continuous process of capturing and verifying data. Similar GRIP projects are now underway in KwaZulu-Natal, Eastern Cape, Free State and Mpumalanga Provinces. The basic GRIP data show that a wealth of information is available if data are captured correctly; the database includes 15500 boreholes and more than 6000 constant discharge tests. Using the GRIP data, scientists for the first time had enough information to present groundwater at pre-feasibility level as a true bulk-water resource.

\section{Requirements}

The case study is situated within the service area of the Nwamitwa Dam situated in Limpopo Province, some $150 \mathrm{~km}$ northeast of Polokwane. Although the dam was designed for a firm yield of some $40 \mathrm{Mm}^{3} / \mathrm{a}$, more recent calculations suggested a firm yield of approximately $14 \mathrm{Mm}^{3} / \mathrm{a}$. The waterresource team, led by BKS, requested assistance from the GRIP team to develop a prefeasibility type report on the availability of water. The final planning deliverables will therefore include the following:

- A discussion with regards to sustainability of well fields compared with surface water schemes

- A map showing proposed well fields within study area

- Each well field should have a detail table capturing sustain- able yields, number of boreholes additional boreholes to obtain yield, borehole depths, cost to drill, water quality, etc. - Well-field development cost, typically capturing borehole development cost, including the borehole, pump, pump house, rising main, command reservoir cost, etc.

\section{General hydrogeology}

Movement of the rock mass created highly fractured zones and may create favourable aquifer conditions. The ASTER images show a long lateral lineament (ASTER Lineament - AL) in the central to southern portion of the study area. During a field visit massive fracturing was observed and corresponded well with interpreted ASTER images. The most favourable places, however, were not in close proximity to towns and difficult to link to any GRIP data.

The contact between the granite and the gneiss is described as gradual and thus not much jointing within the contact zone is expected. It was still investigated as a possible site for the development of aquifers. The granite is an intrusive rock and younger than the gneiss and at depth the gneiss rock mass is expected to have much higher hydrostatic pressure. Therefore at the current erosion surface the difference in stress might lead to slightly more fracturing (joints) in the gneiss compared to the granite. Higher weathering of the joints and more joints at the contact may lead to more favourable aquifer conditions. It is further speculated that boreholes should be placed just off the granite on the gneiss to drill through the gneiss into the granite. In areas north and north-west of Polokwane, Du Toit (2003) did a study on the groundwater availability on the contact between granites intrusions and Hout River Gneiss. He had great success and showed it to be good exploration sites. Du Toit's study was done in a geological setting where the granite intruded into the bedrock, whereas at the Nwamitwa Dam study area the granite mostly formed as a result of melting of the Goudplaats Gneiss to form granite (CGS, 1987). The result thereof may be that the contact between that granite and gneiss may not be prominent. However, south of Giyani it was noted that the contact is visible as biotite-rich pegmatitic material dipping slightly to the south (CGS, 1987). This pegmatite can create favourable aquifer conditions. During a field visit and at some places near Budzu the contacts showed fractured rock with closely spaced jointing and were therefore identified as areas with favourable aquifer conditions.

Both for linear structures and contacts between the gneiss and granite most prominent jointing can be seen within major drainage channels where rocks are exposed. The Badimong and the Molototsi Rivers form topographical lows and were visited during a site visit. A combination of high-density joints and prominent fractures exposed in the riverbeds and directly under well-sorted highly permeable sand creates favourable recharge conditions. Many joint sets visited are open and can easily be targeted.

Most towns, however, are located on topographical highs. As a result, most sites that are favourable for recharge are quite far away from villages. Furthermore, thick overburden at villages makes it much more difficult to pinpoint joints and fracturing, even when using conventional geophysical methods. Gneiss and/or granite weather to form low-permeable soils. Also commonly found in these areas are ferricrete layers which form impermeable subsurface layers within the top and middle areas of topographical heights, further reducing recharge from the vadose zone into the aquifers. Poor land management and poor soil conditions around the villages result in limited 


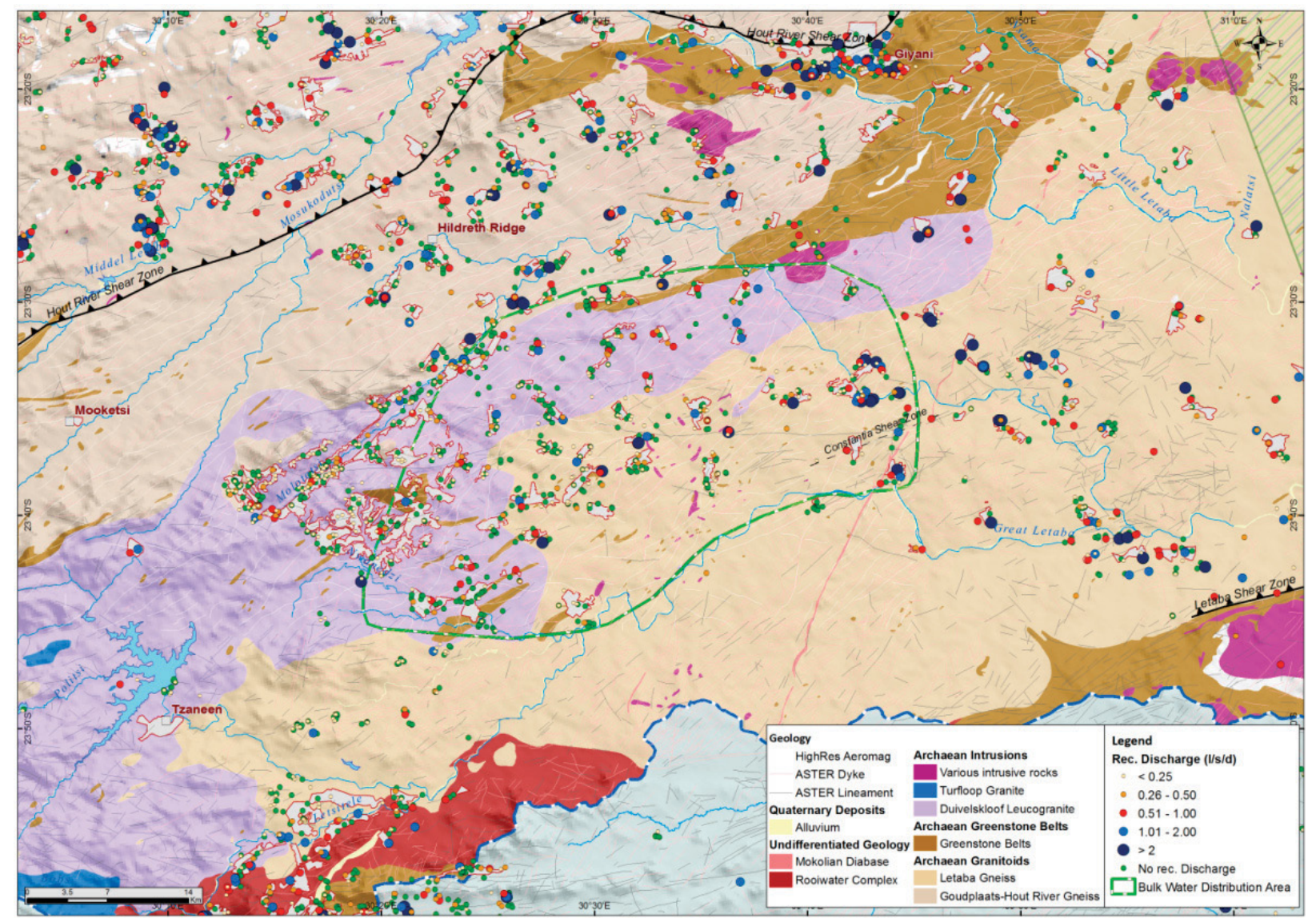

Figure 1

Regional geology of the Nwamitwa case study

vegetation, and therefore there is no rainfall and runoff energy reduction by vegetative soil cover. It was observed that a zone of wasteland was forming around each village.

\section{Results and discussions}

Despite the comprehensive and well-organised Groundwater Resource Information Project (GRIP) dataset, it remains underutilised amongst local and district municipalities throughout the Limpopo Province. Boreholes drilled and tested within the GRIP framework are often over-looked during water supply projects and new boreholes are drilled without consideration to the knowledge obtained from existing data. Tab;e 1 summarises all unequipped and equipped boreholes with recommended yield ( $\ell / \mathrm{s}$ for $24 \mathrm{~h})$. It must be noted that in most cases the recommended yield is given for a single well and does not take into account the cumulative effect of recommended yields on the sustainability of the groundwater resource.

In addition, only $33 \%$ of equipped boreholes produce water that is within acceptable drinking-water quality ranges (Class I) which when combined give a total recommended abstraction rate of $25 \mathrm{Mm}^{3} / \mathrm{a}$. A further $42 \mathrm{Mm}^{3} / \mathrm{a}$, with marginal to poor quality drinking water (Class II and III), can be utilised with prior treatment.

\section{Factors controlling borehole productivity}

Independent or interrelated factors, such as geomorphology (topography), lithology, brittle (neo-) tectonics, and surface water hydrology, all play a significant role in the occurrence of groundwater in crystalline rocks, because together they control:

\begin{tabular}{|l|c|c|c|c|}
\hline \multicolumn{5}{|c|}{ Table 1 } \\
\hline Determined hydrogeological parameter based on the \\
geological setting of boreholes
\end{tabular}

- The nature and depth of the regolith

- The development of fracture and fault zones

- The presence of higher porosity material (or adjacent alluvium)

However, studies regarding the optimal location for highyielding boreholes are rare and the siting of new boreholes is often a wildcard drilling exercise with limited geophysical support. The GRIP dataset, containing borehole productivity indicator data such as transmissivity, recommended borehole yields, drawdown observed during pumping tests together with ASTER lineament interpretation, provides an opportunity to establish the most attractive drilling targets prior to water development projects.

The regional geology and the distribution of the GRIP boreholes for the Nwamitwa Dam case study are provided in Fig. 1. 


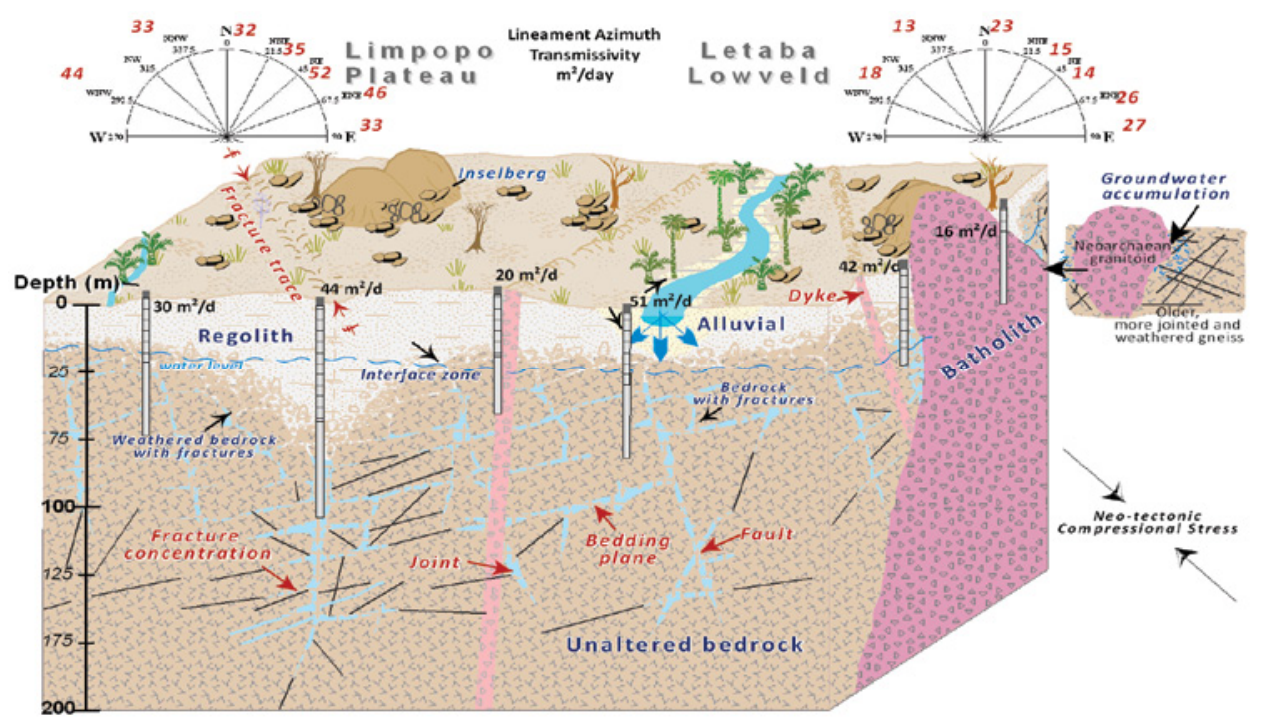

Figure 2

Conceptualisation

of transmissivity values obtained

from various

borehole settings

(Holland and

Witthüser, 2011)

The geological information for each borehole was obtained from the published 1:250 000 geological maps. The identification of 'alluvium' boreholes was based on the published maps as well as $100 \mathrm{~m}$ buffer zones along major river courses. There is a distinct variability in the transmissivities between the lithologies and geological setting of the focus area. The highest transmissivities were - as expected - observed in the primary alluvial aquifers, while the contact zones of the younger granite batholiths provide the highest transmissivities of the basement rocks itself. The younger, large elongated leucogranites together with the main batholith bodies have the lowest transmissivities.

The region has a high dyke and lineament frequency with a strong $\mathrm{NE}$ trend $\left(\mathrm{N} 45^{\circ} \mathrm{E}\right.$ to $\left.\mathrm{N} 50^{\circ} \mathrm{E}\right)$, coinciding with the regional Kudus River- and Tzaneen Lineaments (sub-parallel to the HRSZ). Higher transmissivities are associated with lineaments striking ENE to $\mathrm{E}\left(\mathrm{N} 60^{\circ} \mathrm{E}\right.$ to $\left.\mathrm{N} 90^{\circ} \mathrm{E}\right)$, representing an orientation oblique to the present-day NW-SE maximum horizontal stress. Based on the geological logs, boreholes which encountered diabase or dolerite (dykes) have generally lower transmissivities and yields than boreholes devoid of diabase/ dolerite. Notably higher borehole productivities are observed within the $50 \mathrm{~m}$ to $150 \mathrm{~m}$ range compared to boreholes further than $150 \mathrm{~m}$. It can be generally accepted that lineaments have a positive influence on borehole productivity and should be considered for future drilling programmes.

To determine the influence of drainage channels on the borehole productivity, a spatial assessment of proximity was conducted. Remarkably, $55 \%$ of all boreholes in the dataset are drilled within $150 \mathrm{~m}$ to streams or rivers as mapped on the 1:50 000 topographic maps of South Africa. Nineteen percent of these are along the major drainage channels with remarkably enhanced transmissivities and yields. Drainage channels often follow zones of structural weaknesses (e.g. lineaments) in the near surface; therefore rocks in the vicinity of rivers can be more intensely fractured, jointed and/or weathered.

\section{Conceptualisation}

The Limpopo basement lithologies can be characterised by a generally thin regolith where groundwater aquifers are primarily structurally controlled. The current conceptual understanding of the most significant features controlling borehole yields in the Limpopo basement lithologies is illustrated in Fig. 2 Based on the results it seems that higher borehole productivities are in fact associated with lineaments and dykes perpendicular to the current stress regime, more specifically ENE to E and WNW to W. Due to the complex geological history of the area, it is difficult to link these open discontinuities to a distinct recent or past tectonic event. The hydrogeological importance of several factors on groundwater occurrence presented can be used as a working reference for groundwater development programmes, in order to narrow down exploration targets to the most influential factors.

\section{Hydrogeological targets}

The team used the geological and the GRIP information to identify areas that might have led to the development of high yielding aquifers. These areas include linear structures, granite and gneiss contacts combined with enhanced aquifer conditions within drainage areas. As a result several drainage channels where identified as potential areas to be reviewed (Fig. 3)

\section{Detailed site assessment}

A site-specific investigation was done for a site in the most southern part of the service supply zone. This area is furthest from the proposed Nwamitwa Dam and from time to time is likely to experience water shortages. Using the ASTER data geological lineaments within close proximity to the Molototsi River was sited. The potential lineaments were verified in the field, followed by ground geophysics to pinpoint possible groundwater exploration sites. Some fractures were so profound that they were pinpointed using only geological interpretation.

In total 22 boreholes were drilled with an average yield of $3.3 \mathrm{\ell} / \mathrm{s} / \mathrm{s}$ with 9 boreholes having blow yields of $4 \mathrm{\ell} / \mathrm{s}$ or more and only 2 dry boreholes. The average depth of the boreholes was $120 \mathrm{~m} \mathrm{bgl} \mathrm{(metres} \mathrm{below} \mathrm{ground} \mathrm{level)} \mathrm{and} \mathrm{the} \mathrm{average} \mathrm{last}$ water strike was at $80 \mathrm{~m}$ bgl, with the deepest water strike a deep $175 \mathrm{~m}$ bgl. Sustainable yields ranged between $0.3 \mathrm{l} / \mathrm{s}$ and $4.5 \mathrm{l} / \mathrm{s}$ and the water quality was classified as Class 2, Class 3 and Class 4 (Table 2). Most of the borehole water samples showed total hardness (TH) and total dissolved solids (TDS) as being too high (Class 2) and it seems that cadmium (Cd) and arsenic (As) can also be somewhat elevated. 


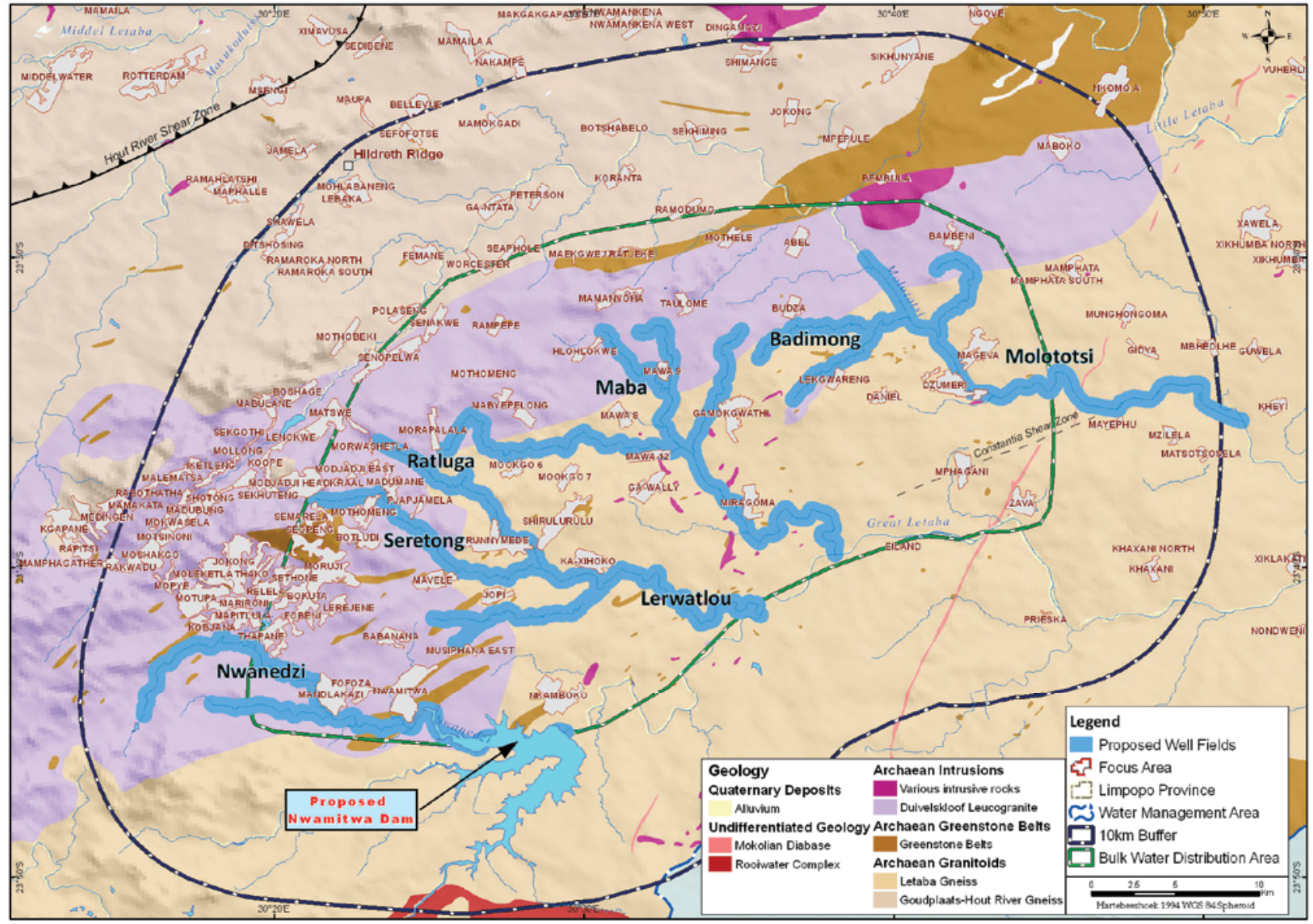

Figure 3

High yielding areas identified as possible well-fields

\begin{tabular}{|c|c|c|c|c|c|c|c|c|}
\hline & & & & stainabl & le recom & $\begin{array}{c}\text { Table } 2 \\
\text { imended yields and water qu }\end{array}$ & ality summary & \\
\hline Borehole & Constant & Sus & ainable & yield & & Water C & uality & Monitoring \\
\hline & $\begin{array}{c}\text { test yield } \\
(\ell / s)\end{array}$ & $\begin{array}{l}\text { Rate } \\
(\ell / s)\end{array}$ & $\begin{array}{l}\text { Pump } \\
\text { cycle }\end{array}$ & $\begin{array}{c}\begin{array}{c}\text { Volume } \\
\left(\mathrm{m}^{3} / \mathrm{d}\right)\end{array} \\
\end{array}$ & $\begin{array}{c}\text { Chemi- } \\
\text { cal }\end{array}$ & Elements & Bacteriological & boreholes \\
\hline H14-0786 & & & & & Class 2 & $\mathrm{TH}$ & Class $2-$ Total \& faecal coliforms & \\
\hline H14-0787 & 12.33 & 4.5 & 24 & 388.8 & Class 2 & As, $\mathrm{Cd}, \mathrm{TH}$ & & $\begin{array}{l}\text { H14-0786, } \\
\text { H14-0789 }\end{array}$ \\
\hline H14-0789 & 12.55 & 4.5 & 24 & 388.8 & Class 2 & $\mathrm{TH}$ & & $\begin{array}{l}\text { H14-0786, } \\
\text { H14-0787 }\end{array}$ \\
\hline H14-0790 & 2.20 & 0.8 & 24 & 69.12 & Class 2 & $\mathrm{TH}, \mathrm{As}$ & & \\
\hline H14-0960 & & & & & & & & \\
\hline H14-0968 & & & & & & & & \\
\hline H14-0981 & & & & & & & & \\
\hline H14-0986 & None & & & & Class 2 & Ec, TDS, TH, Na, Cl & Class $2-$ Total \& faecal coliforms & \\
\hline H14-0999 & & & & & & & & \\
\hline H14-1000 & & & & & & & & \\
\hline H14-1001 & None & 0.3 & 12 & 12.96 & Class 3 & TH & Class 3 - Total coliforms & \\
\hline H14-1002 & 5.28 & 1.7 & 24 & 146.9 & Class 2 & $\mathrm{TH}, \mathrm{As}, \mathrm{Mn}$ & & \\
\hline H14-1347 & & & & & & & & \\
\hline H14-1698 & 0.9 & 0.2 & 24 & 17.28 & Class 2 & TH, EC, Na, F, Cl, As & & \\
\hline H14-1699 & 3.01 & 1.0 & 24 & 86.4 & Class 2 & $\mathrm{TH}, \mathrm{EC}, \mathrm{TDS}, \mathrm{As}, \mathrm{Na}, \mathrm{Cl}$ & & \\
\hline H14-1700 & None & 0.1 & 3 & 54 & Class 3 & TH, EC, TDS, As, Na, F, Cl & Class 4-Total coliforms & \\
\hline H14-1701 & & & & & & & & \\
\hline H14-1702 & 10.1 & 1.8 & 24 & 155.5 & Class 3 & $\mathrm{TH}, \mathrm{EC}, \mathrm{TDS}, \mathrm{Cl}$ & & \\
\hline H14-1703 & 16.19 & 4.5 & 24 & 388.8 & Class 2 & $\mathrm{TH}, \mathrm{As}, \mathrm{EC}, \mathrm{TDS}, \mathrm{Na}, \mathrm{Cl}$ & Class 3 - Total coliforms & $\begin{array}{l}\mathrm{H} 14-1698, \\
\mathrm{H} 14-1699\end{array}$ \\
\hline
\end{tabular}


Yield curve

Well-fields versus surface scheme

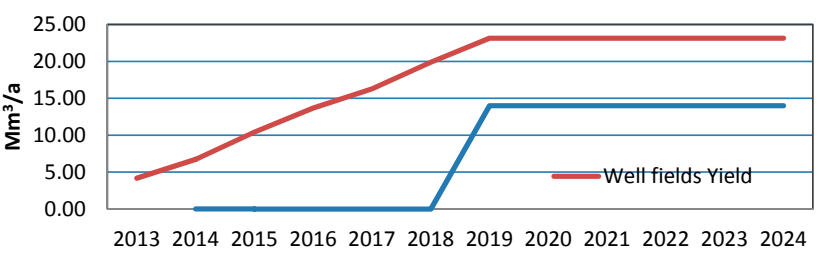

Figure 4

Example of well-field yield compared with possible surface-scheme yield

\section{Proposed Nwamitwa well-field development}

In total, 7 potential well-fields were identified (Fig. 3). The well-fields are associated with fracturing; therefore recharge occurs both from rainfall recharge and river recharge, commonly referred to as a losing river. Construction of a massive in-channel storage dam is not required; water is simply stored underground rather than above ground. There is also less influence on natural flood events and more water available downstream for users.

A major advantage of groundwater is that it can be developed within close proximity to the user as can be seen in Fig. 3. Another advantage is the rapid development of groundwater resources. Given a period of 18 months for designs and EIAs and 1 year for construction the first well-field could produce potable water in early 2013. A number of drilling rigs can be deployed within the proposed well-field development zone and within a 2-month period most boreholes can be drilled and tested. The pipeline, balancing dams and command reservoir have the longest lead items, but can also be completed within a 1 -year period.

Based on the exploration data, 3 production borehole yield types were selected $(1.5 \mathrm{l} / \mathrm{s}, 3 \mathrm{l} / \mathrm{s}$ and $4.5 \mathrm{\ell} / \mathrm{s})$ and lengths of the proposed well-fields were estimated. To ensure that localised dewatering does not occur, it was decided to keep boreholes $500 \mathrm{~m}$ apart. Individual boreholes were selected to achieve a borehole density of higher than $500 \mathrm{~m}$ between boreholes and boreholes with yields of $4.5 \mathrm{l} / \mathrm{s}$ were limited to a distance of $1300 \mathrm{~m}$. Estimated borehole yields from each borehole were added up to estimate well-field yields. Proposed well-field yields varied between $2.6 \mathrm{Mm}^{3} / \mathrm{a}$ and $4.2 \mathrm{Mm}^{3} / \mathrm{a}$.

In addition, well-fields can be constructed in a consecutive manner or as the need arises; for this study it is shown as consecutive development. Compared to surface water resources, capital expenditure almost immediately results in available water supply (Fig. 4). Further to this, conventional storage schemes capture water from 1 catchment only whereas wellfields can access more catchments and cumulatively harvest more water.

The overarching aim is to illustrate the value of conjunctive use and therefore short- to medium-term solutions provided by groundwater need to be combined with surface-water solutions to provide the optimum solution, where groundwater resources can be developed first, followed by a surface-water resource (Fig. 5).

\section{Well-field development cost}

Based on phased implementation, the model was created to better estimate groundwater development cost. Using minimum capital cost, groundwater can be developed and can
Yield curve

Conjunctive scheme

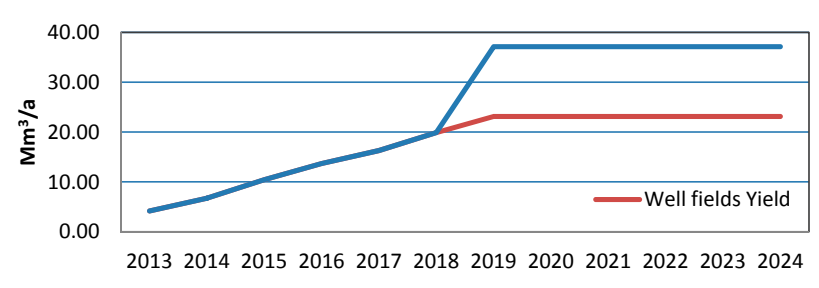

Figure 5

Combined yield curve for groundwater and surface water

immediately generate revenues. Considering the world markets and the unwillingness of banks to lend money for development, it was decided to select a high interest rate of $20 \%$ and for the purpose of this study the price of water (income) was set at $\mathrm{R} 2 / \mathrm{m}^{3}$. The model shows that a capital investment of about R380 million may be sufficient to develop well-fields which will start to be self-sufficient in about 2018 and 2019.

\section{Development and operational strategy}

Like all bulk resources it can either be developed by government (DWA) or a semi-government organisation, for example the Trans-Caledon Tunnel Authority (TCTA). A water board or municipality can also develop and operate the groundwater resources. They simply need to license the water use; it is a social/political decision not discussed in this report.

Installation of a modern telemetry data-management system is recommended as it will ensure easy operation and management, and to manage the well-field according to wellfield availability and water-demand requirements. These systems are used in the mining sector to ensure availability of water supply and some municipalities in the Western Cape also use these systems to manage their water supply. The great advantage is that water levels, volume, electricity consumption, etc., are all recorded and an alarm is triggered if it runs outside set parameters.

\section{Conclusions and recommendations}

Within the South African context, groundwater has not been used at this scale to develop a rural bulk-water scheme and the real costs and benefits were never tested in a scheme. The GRIP dataset makes it possible for the user to apply it and gives decision-makers a glimpse of what may be it South Africa take a bold step forward and develop groundwater as a bulk-water resource. The GRIP dataset was used to accurately describe the hydrogeological conditions within the sturdy area and to show that it is possible to find high-yielding boreholes within the area.

A site-specific investigation demonstrated that it is possible to locate new high-yielding boreholes and chemical and bacteriological data show all boreholes to be Class 2, 3 or 4 and raw water is not suitable for domestic supply. As a result of these findings and pending additional long-term borehole tests and subsequent chemical analyses of high-yielding boreholes, the costs to treat the water to potable standards may still have to be added to the development costs.

Preliminary results, however, show that well-fields can be rapidly developed at $\mathrm{R} 2 / \mathrm{m}^{3}$ and requires capital input of roughly R380 million over a period of 7 years to 8 years. In addition, well-fields should be managed like any other bulkwater resource and a telemetry data-management system 
should be used to improve operation thereof. Typically a water board or municipality should take responsibility for a well-field and manage it in a sustainable manner.

\section{References}

BARON J, SEWARD P and SEYMOUR A (1996) The Groundwater Harvest Potential Map of the Republic of South Africa. DWAF Report No. Gh3917. Department of Water Affairs and Forestry, Pretoria, South Africa.

BOTHA FS (2005) A Proposed Method to Implement a Groundwater Resource Information Project (GRIP) in Rural Communities, South Africa. Ph.D. Thesis. University of the Free State, Bloemfontein, South Africa.

BOTHA FS, VELTMAN S, WEIDEMANN R and FOURIE F (2009) Aquifer boundaries versus economic development, Lephalale, South Africa. Proc. Groundwater 2009 Conference. 16-18 November 2009, Cape Town, South Africa.

COUNCIL FOR GEOSCIENCE (CGS) (1987) Explanation Sheet 2330 (1:250 000). Council for Geoscience, Pretoria, South Africa.

DWAF (DEPARTMENT OF WATER AFFAIRS AND FORESTRY, SOUTH AFRICA) (2004) National Water Resource Strategy $\left(1^{\text {st }}\right.$ edn.). Department of Water Affairs and Forestry, Pretoria, South Africa.

DWAF (DEPARTMENT OF WATER AFFAIRS AND FORESTRY, SOUTH AFRICA) (2007) Artificial Recharge Strategy. Version 1.3 - June 2007. Department of Water Affairs and Forestry, Pretoria, South Africa.
DWA (DEPARTMENT OF WATER AFFAIRS, SOUTH AFRICA) (2009) Strategic Planning for Water Resources in South Africa, Situation Analysis. Department of Water Affairs, Pretoria, South Africa.

DU TOIT WH (2003) The Influence of Granite Intrusions on the Host Rocks in Terms of Occurrence of Groundwater in the Pietersburg Area. M. Tech. Thesis. Faculty of Natural Sciences, Technikon Pretoria, South Africa.

GRIP LIMPOPO (2002) Limpopo Groundwater Resource Information Project (GRIP) - An initiative of the Department of Water Affairs (DWA) to collate groundwater information and establish a groundwater information system for the Limpopo Province. Online v.2.0. URL: http:/griplimpopo.co.za/login.php (Accessed 25 November 2010).

HAUPT CJ (2001) Ground Water Resources of South Africa. WSM Report for Directorate of Water Resource Planning. DWAF Report No. 97128, April edition. Department of Water Affairs and Forestry, Pretoria, South Africa.

HOLLAND M and WITTHÜSER KT (2011) Evaluation of geologic and geomorphologic influences on borehole productivity in crystalline bedrock aquifers of Limpopo Province, South Africa. Hydrogeol. J. 19 1065-1083. DOI: 10.1007/s10040-011-0730-5.

RSA (REPUBLIC OF SOUTH AFRICA) (1998) National Water Act. Act No. 36 of 1998. Republic of South Africa. Government Gazette No. 19182.

VEGTER JR (2001) Groundwater Development in South Africa and an Introduction to the Hydrogeology of the Groundwater Regions. WRC Report No. TT 134/00. Water Research Commission, Pretoria, South Africa. 
http://dx.doi.org/10.4314/wsa.v38i3.4 Available on website http://www.wrc.org.za

ISSN 0378-4738 (Print) $=$ Water SA Vol. 38 No. 3 International Conference on Groundwater Special Edition 2012 ISSN 1816-7950 (On-line) = Water SA Vol. 38 No. 3 International Conference on Groundwater Special Edition 2012 